\title{
The dynamics of biomass and nutrient accumulation in a Douglas- fir (Pseudotsuga menziesii Franco) stand studied using a chronosequence approach
}

\author{
Jacques Ranger*, Renato Marques, Micheline Colin-Belgrand, Nathalie Flammang, \\ Dominique Gelhaye \\ INRA Centre de Nancy, Equipe Cycles Biogéochimiques, Champenoux, 54280 Seichamps, France
}

Accepted 11 August 1994

\begin{abstract}
Douglas-fir is presently one of the dominant species used in France for afforestation. It was widely introduced without knowing exactly its effects on soils and superficial waters. The aim of this research was to obtain quantitative data on the biogeochemical functioning of a Douglas-fir ecosystem, and to provide relevant information to forest managers. The results presented here concern nutrient accumulation on a stand according to its stage of development.

A chronosequence of stands was used to rapidly obtain information on ecosystem dynamics in particular because it is possible to assimilate stands of different ages to the different stage of development of a single stand.

The present results make it possible to evaluate with sufficient accuracy nutrient losses at crop harvest. Several scenarios could be drawn using various rotation lengths and harvesting intensities. These results could be introduced in management models. Nevertheless, a direct relationship between nutrient losses and the immediate or delayed decrease of forest productivity is not easy to predict. It depends more on soil nutrient dynamics than on the present available nutrient pool.

Comparison between the two main species used in forestry showed that the nutrient efficiency of Douglas-fir for biomass production was at least the same as for Norway spruce. This important conclusion needs to be confirmed by other measurements.
\end{abstract}

Keywords: Douglas-fir; Stage of development; Biomass; Nutrient content; Nutrient use efficiency

\section{Introduction}

Douglas-fir was first introduced in France in 1850 and has now become one of the main species used for afforestation with a total area of about 300000 ha and about 7000-8000 ha planted each year. This species has the highest

* Corresponding author. potential for wood production under French climatic and ecological conditions: Bouchon (1982) evaluated the mean annual increment at $17 \mathrm{~m}^{3} \mathrm{ha}^{-1}$ year $^{-1}$ for stands distributed all over the country.

The lack of information on nutrient requirements and effects of Douglas-fir silviculture on the environment spurred us to investigate this field. 
Worldwide research on nutrient cycles has been carried out at one particular stage of stand development, generally on the mature stage. More relevant information in the field of nutrient dynamics according to stand development needs to be obtained.

This work is part of a general investigation, the aim of which is to determine the ecological basis for stand management and to identify the effects of Douglas-fir plantations on the environment and particularly on soils and superficial waters. The total loss of nutrients from the ecosystem by biomass harvesting and by deep drainage will be evaluated and the potential of the soil to supply these elements will be investigated to prevent soil nutrient depletion and to ensure the perenniality of the production.

This particular part of the study will be focused on the effect of stand age on nutrient uptake, nutrient storage (immobilisation) and nutrient efficiency for biomass production.

\section{Materials and methods}

\subsection{Practical organisation of the project}

Owing to the longevity of forest species it is evident that forest ecosystem dynamics cannot be easily studied. Simply observing such a system for a few years is not sufficient. An adequate, and currently the most frequently applied method, is the chronosequence approach which provides a means by which long-term changes in ecosystem structure and processes can be assessed within a reasonable time frame (Cole and Van Miegroet, 1989). It is clear that chronosequences cannot replace real long-term field experiments (Burger and Powers, 1991) which nevertheless have many disadvantages (delay in obtaining results, workload and, not least, particular tendencies in external parameters, i.e. climate) which can cause a systematic bias in the observations.

The selection of an age sequence of stands implies major constraints:

(i) all the stands have to belong to the same tree species, with preferably the same geograph- ical tree provenance, but this information is not often available;

(ii) the stands must be situated in the same ecological conditions (topography, aspect, soil type, water regime, etc. );

(iii) the silviculture of the stands must have been and continue to be the same;

(iv) the land use history of the site should be the same.

In practice, these constraints cannot be completely satisfied simultaneously. However, some satisfactory situations can be found where it is possible to relate the different stands to the different stages of development of a single stand.

The Douglas-fir has been widely introduced in the Beaujolais mountains since the last quarter of the nineteenth century for historical reasons. Therefore, this region is best suited for selecting a research site.

\subsection{Stand characteristics}

Three stands were selected according to the criteria previously described. They were situated in the forêt des Aiguillettes in the Beaujolais mountains (Rhône, France). Their main characteristics are shown in Table 1. According to Decourt (1967) the stands belong to fertility class 1 of the Douglas-fir yield table established for the northeast Massif Central (France) including the Beaujolais area. The dendrometric parameters observed are in agreement with those of the mean stand development described in the yield table.

Table 1

Stand characteristics (mean $\pm \mathrm{SD}$ )

\begin{tabular}{llll}
\hline & \multicolumn{2}{l}{ Stand age (years) } & \\
\cline { 2 - 4 } & 20 & 40 & 60 \\
\hline Height (m) & $14.3 \pm 2.1$ & $28.2 \pm 2.7$ & $36.3 \pm 2.7$ \\
CBH (cm) & $57.0 \pm 15.3$ & $104.7 \pm 27.1$ & $163.7 \pm 39.1$ \\
$\begin{array}{l}\text { Stand density } \\
\text { (no. trees ha }\end{array}$ & 922 & 490 & 312 \\
\hline
\end{tabular}




\subsection{Ecological situation}

The site studied is situated at an altitude of 650 $\mathrm{m}$. The climate has the following main characteristics: a mean annual temperature of $7{ }^{\circ} \mathrm{C}$ and mean annual precipitation of $1000 \mathrm{~mm}$. Rainfall is more or less evenly distributed throughout the year with a small maxima in summer; 150 days of fog and 38 days of snow per year were observed. The bedrock is a Devono-Dinantian volcanic rock of the 'ignimbrite' type, which gives a rather rich saprolite by weathering processes. The soil is a Typic Dystrochrept (Soil Survey Staff, 1975 ) type. Soil characteristics are given in Table 2. The fraction less than $2 \mathrm{~mm}$, has a fine texture, but is often stony ( $20-50 \%$ of large stones depending on soil horizons). Soil is acidic with a $\mathrm{pH}\left(\mathrm{H}_{2} \mathrm{O}\right)$ range of the solid phase from 4.1 to 4.4 in the $\mathrm{A}$ horizons and a base saturation from 0.05 to 0.20 meq per $100 \mathrm{~g}$ for $\mathrm{Ca}$ and $0.05-0.15$ meq for $\mathrm{Mg}$. Exchangeable $\mathrm{Al}$ occupies a large part of the sites of the cation exchange capacity (CEC) with values varying from 4 to 8 meq per $100 \mathrm{~g}$ according to soil layers. The total $\mathrm{Ca}, \mathrm{K}$ and $\mathrm{Mg}$ content is $0.2 \%, 3.0 \%$ and $0.7 \%$ respectively.

Roots develop mainly in the top $50 \mathrm{~cm}$ but many can be found at a depth of $80-100 \mathrm{~cm}$.

\subsection{Methodology to evaluate biomass and nutrient storage}

A special method was progressively adopted to accurately evaluate the biomass and mineral content of forest stands (Ranger, 1981; Bouchon et al., 1985; Ranger et al., 1992).

For the present study, this method can be summarised as follows.

(1) The inventory of the stand was carried out on a $0.05-0.2$ ha area according to stand density and stand age.

(2) Twelve trees per stand (distributed throughout all the girth classes defined from the inventory) were cut down and the major components were isolated: needles (1 year old or more), branches ( 1 year old or more), stemwood and stembark. The following parameters were measured. The diameter of branches $10 \mathrm{~cm}$
$\left(D_{10}\right)$ from the insertion on the stem and position of the whorls systematically measured for all the branches. A sample of three branches per tree, selected according to diameter and position, was taken in which needles 1 or more years old and branches 1 or more years old were immediately isolated and put into plastic bags for weight and water content measurement in the laboratory. Stem circumference was measured at 0.50 $\left(C_{0.50}\right), 1.30\left(C_{1.30}\right)$, and every $3 \mathrm{~m}$, total length and position of the first living branch were noted. Samples were taken for volume increment, wood density, water and nutrient content measurements.

(3) Biomass and nutrient content tables were established. Special attention was paid to obtain common provisional tables for the three stands. Models were selected according to the following constraints: no bias, maximum explanation of the variance and minimum residues.

(4) These tables were then applied to the inventory of the different stands to evaluate stand biomass and nutrient content for each component previously defined.

The current annual uptake of nutrients of a stand was evaluated according to the following formula (Ranger and Bonneau, 1984)

Uptake $=$ Immobilisation + restitutions $($ litterfall and leaching of nutrients by precipitation)

The annual increment and the mean concentration of the trunk will be used to evaluate the current annual immobilisation of nutrients (definitive nutrient storage, not able to change with time). The litterfall of each stand was measured from 20 litter traps per stand. Litter was collected every 3 months.

Biomass and nutrients, collected during thinning operations were evaluated from forest managers' data and present chemical composition of the material according to its age.

\subsection{Chemical sample analyses}

All the samples of branches, 1 year old or more for needles and 'wood', were analysed for major nutrients $(\mathrm{N}, \mathrm{P}, \mathrm{K}, \mathrm{Ca}, \mathrm{Mg})$. For the stems, a 
mean weighted sample per tree, for bark and wood separately, was analysed for the same elements and also for $\mathrm{S}$ and $\mathrm{Mn} . \mathrm{P}, \mathrm{K}, \mathrm{Ca}, \mathrm{Mg}, \mathrm{S}$, Mn were determined after acid digestion of the finely ground material by ICP spectrophotometry (Jobin-Yvon JY $38^{+}$). Total $\mathrm{N}$ was determined by colorimetry on a Technicon II autoanalyser after Kjeldahl mineralisation. Five hundred samples were analysed using this procedure.

\subsection{Statistical data processing}

Graphics and elementary statistics were operated on a Macintosh Apple microcomputer with the Cricket and Statview software. Biomass and nutrient content tables were modelled using the SAS software on UNIX system. The main steps of the calculation and the criteria required for the tables were as follows (Flammang, 1992).

(1) Selection of the variables potentially useful for the model from the global correlation matrix.

(2) Simple representation of data on graphics to identify the type of mathematical function which fits better.

(3) Linear regression between biomass or nutrient content of a component and the dendrometric parameter(s) used for the inventory was tested independently for each stand.

The backward option of SAS was chosen to eliminate the non significant variable(s) initially introduced into the model. Criteria for a valid model were as follows (these were calculated systematically for each stand, component and element):

(i) reliability of the model given by a maximum adjusted $R^{2}$ value and a minimum root mean square error (RMSE);

(ii) reliability of the model given by the observation of the residues (calculated values-observed values) $=f$ (calculated values) where no statistical relationship must appear.

(4) A common model for the three stands was systematically sought. This goal is achieved if a maximum of common variables participate in the individual tables per stand. The common model equation was derived by exploring the behaviour of variables of the individual stand model as a function of stand age. It was then necessary to determine the best expression of the 'age effect' on the parameters; linear, polynomial or reverse functions were tested. The general requirements for the reliability of the model were the same as previously described for the individual models. The last step for the acceptance of the model was observing the simulated values for whole tree populations. Problems will occur if the sampling zone and the whole population spectrum of variation do not coincide. Some differences occurred in the calculations between the stem and the canopy. For the stem it was possible to directly establish a model using the dendrometric parameter of the inventory, i.c. $C_{130}$, as an explanatory variable for evaluating the biomass or nutrient content of this component. This was first done at the stand level, and then a common model was established for the three stands of the chronosequence. For the canopy it was necessary to use embedded models. First, to model the biomass or nutrient content of a branch component using diameter, age and/or position in the crown as explanatory variables, for a stand and then for the three stands. This model was then applied to the inventory of branches to calculate the biomass and nutrient content of each tree canopy. Secondly to model the biomass and nutrient content of the canopies according to tree size parameter i.e. $C_{130}$ per stand and then for the three stands.

\section{Results}

\subsection{Qualitative aspect of nutrient distribution into the stands}

The general status of stand nutrition has been investigated by foliar analysis (Table 3 ) on samples taken on the upper part of the crown (1-yearold needles taken from branches of the ten upper whorls) in November 1991.

The distribution of major nutrients is summarised in Table 4. Comparison between stands shows that the same general classification of components is observed for the three stands: 
Table 2

Main soil characteristics for the 60-year-old stand. Data supplied are for air-dry material except for granulometry and total analysis (material dried at $105^{\circ} \mathrm{C}$ )

\begin{tabular}{|c|c|c|c|c|c|c|c|c|c|}
\hline & \multicolumn{9}{|c|}{ Soil layer } \\
\hline & $\begin{array}{l}\text { AlAp } \\
0-10\end{array}$ & $\begin{array}{l}\text { Ap2 } \\
(10-20 \\
\mathrm{cm})\end{array}$ & $\begin{array}{l}\mathrm{Ap}(\mathrm{B}) \\
(20-35 \\
\mathrm{cm})\end{array}$ & $\begin{array}{l}\text { (B) } 1 \\
(35-50 \\
\mathrm{cm})\end{array}$ & $\begin{array}{l}\text { (B) } 2 \\
(50-65 \\
\mathrm{cm})\end{array}$ & $\begin{array}{l}\text { (B) } 3 \\
(65-75 \\
\mathrm{cm})\end{array}$ & $\begin{array}{l}\text { (B)/C } \\
(75-85 \\
\mathrm{cm})\end{array}$ & $\begin{array}{l}\mathrm{C} 1 \\
(85-100 \\
\mathrm{cm})\end{array}$ & $\begin{array}{l}\mathrm{C} 2 \\
(100- \\
110 \mathrm{~cm})\end{array}$ \\
\hline \multicolumn{10}{|l|}{ Granulometry } \\
\hline Clay $\%$ & 19.8 & 20.3 & 22.1 & 25.1 & 16.9 & 18.1 & 17.4 & 13.7 & 13.9 \\
\hline Silt \% & 40.5 & 42.7 & 42.2 & 40 & 36 & 33.6 & 34.2 & 38.3 & 35.7 \\
\hline Sand \% & 39.7 & 37 & 35.7 & 34.9 & 47.1 & 48.3 & 48.4 & 48 & 50.4 \\
\hline Org. matter (\%) & 8.15 & 3.85 & 3.06 & 1.15 & 0.55 & 0.33 & 0.33 & 0.28 & 0.28 \\
\hline Norg. (\%) & 0.37 & 0.206 & 0.147 & 0.068 & 0.038 & 0.024 & 0.022 & 0.02 & 0.019 \\
\hline $\mathrm{C} / \mathrm{N}$ & 12.8 & 10.9 & 12.1 & 9.9 & 8.4 & 7.9 & 8.6 & 8.0 & 8.4 \\
\hline \multicolumn{10}{|l|}{ Total elements } \\
\hline Ca tot. $(\%)$ & 0.09 & 0.08 & 0.08 & 0.06 & 0.07 & 0.17 & 0.18 & 0.28 & 0.15 \\
\hline $\mathrm{Mg}$ tot. $(\%)$ & 0.50 & 0.49 & 0.57 & 0.62 & 0.71 & 0.79 & 0.87 & 0.89 & 0.93 \\
\hline $\mathrm{K}$ tot. $(\%)$ & 3.17 & 3.30 & 3.38 & 3.48 & 3.66 & 3.71 & 3.75 & 3.68 & 3.60 \\
\hline $\mathrm{P}_{2} \mathrm{O}_{5}$ tot. $(\%)$ & 0.16 & 0.15 & 0.17 & 0.15 & 0.15 & 0.10 & 0.08 & 0.07 & 0.07 \\
\hline \multicolumn{10}{|l|}{ Free elements } \\
\hline $\begin{array}{l}\text { Al Tamm } \\
(\%)\end{array}$ & 0.62 & 0.46 & 0.39 & 0.33 & 0.23 & 0.20 & 0.19 & 0.19 & 0.20 \\
\hline Fe DCB (\%) & 0.93 & 0.86 & 0.90 & 0.90 & 0.86 & 0.69 & 0.59 & 0.62 & 0.58 \\
\hline $\mathrm{pH}\left(\mathrm{H}_{2} \mathrm{O}\right)$ & 4.1 & 4.3 & 4.4 & 4.5 & 4.4 & 4.4 & 4.4 & 4.5 & 4.5 \\
\hline \multicolumn{10}{|c|}{ Exchangeable elements } \\
\hline $\mathrm{K}(\mathrm{meq} \%)$ & 0.20 & 0.19 & 0.15 & 0.13 & 0.13 & 0.14 & 0.15 & 0.17 & 0.17 \\
\hline $\mathrm{Ca}(\mathrm{meq} \%)$ & 0.18 & 0.08 & 0.07 & 0.06 & 0.05 & 0.05 & 0.03 & 0.07 & 0.05 \\
\hline $\mathrm{Mg}(\mathrm{meq} \%)$ & 0.15 & 0.07 & 0.05 & 0.03 & 0.03 & 0.03 & 0.05 & 0.05 & 0.04 \\
\hline Mn (meq\%) & 0.07 & 0.03 & 0.03 & 0.02 & 0.01 & 0.01 & 0.02 & 0.01 & 0.01 \\
\hline $\mathrm{Fe}(\mathrm{meq} \%)$ & 0.02 & 0.00 & 0.00 & 0.00 & 0.00 & 0.00 & 0.00 & 0.00 & 0.00 \\
\hline $\mathrm{Na}(\mathrm{meq} \%)$ & 0.05 & 0.11 & 0.02 & 0.00 & 0.03 & 0.00 & 0.06 & 0.05 & 0.11 \\
\hline $\mathrm{Al}(\mathrm{meq} \%)$ & 7.5 & 4.4 & 4.5 & 4.1 & 4.1 & 4.5 & 4.9 & 5.0 & 4.6 \\
\hline BC & 0.57 & 0.44 & 0.30 & 0.22 & 0.25 & 0.22 & 0.28 & 0.33 & 0.37 \\
\hline $\mathrm{BC} / \mathrm{CEC}(\%)$ & 7.0 & 9.1 & 6.4 & 5.2 & 5.6 & 4.7 & 5.4 & 6.2 & 7.6 \\
\hline CEC & 8.2 & 4.8 & 4.8 & 4.3 & 4.4 & 4.7 & 5.2 & 5.3 & 4.9 \\
\hline $\mathrm{P}_{2} \mathrm{O}_{5}$ avail. (\%) & 0.02 & 0.01 & 0.01 & 0.01 & 0.01 & 0.01 & 0.01 & 0.01 & 0.01 \\
\hline
\end{tabular}

Table 3

Foliar analysis data for the current year needles in 1991 (date expressed as percentage of dry matter at $65^{\circ} \mathrm{C}$ )

\begin{tabular}{llllll}
\hline Stand age (years) & $\mathrm{N}$ & $\mathrm{P}$ & $\mathrm{K}$ & $\mathrm{Ca}$ & $\mathrm{Mg}$ \\
\hline 20 & 1.71 & 0.21 & 0.74 & 0.40 & 0.14 \\
40 & 1.53 & 0.13 & 0.62 & 0.26 & 0.11 \\
60 & 1.58 & 0.13 & 0.56 & 0.38 & 0.12 \\
Ref. for Douglas-fir (Bonneau, 1988) & $1.5-1.9$ & $0.15-0.16$ & $0.6-0.8$ & $0.3-0.5$ & $0.1-0.14$
\end{tabular}


Table 4

Mean concentration of major nutrients in the various components according to stand age (data expressed as a percentage of dry matter). Standard deviation is given in parentheses

\begin{tabular}{|c|c|c|c|c|c|c|c|c|c|}
\hline & \multicolumn{3}{|l|}{$N$} & \multicolumn{3}{|l|}{$P$} & \multicolumn{3}{|l|}{ K } \\
\hline & 20 years & 40 years & 60 years & 20 years & 40 years & 60 years & 20 years & 40 years & 60 years \\
\hline \multicolumn{10}{|l|}{ Branches } \\
\hline Needles 1 year & $\begin{array}{r}1.60 \mathrm{a} \\
(0.10)\end{array}$ & $\begin{array}{r}1.64 a \\
(0.18)\end{array}$ & $\begin{array}{r}1.52 \mathrm{~b} \\
(0.14)\end{array}$ & $\begin{array}{r}0.11 \mathrm{a} \\
(0.01)\end{array}$ & $\begin{array}{r}0.11 \mathrm{a} \\
(0.02)\end{array}$ & $\begin{array}{r}0.12 \mathrm{a} \\
(0.02)\end{array}$ & $\begin{array}{r}0.58 \mathrm{a} \\
(0.11)\end{array}$ & $\begin{array}{l}0.53 \mathrm{ab} \\
(0.11)\end{array}$ & $\begin{array}{l}0.51 \mathrm{~h} \\
(0.12)\end{array}$ \\
\hline Needles $>1$ year & $\begin{array}{r}1.56 a \\
(0.19)\end{array}$ & $\begin{array}{r}1.66 \mathrm{a} \\
(0.22)\end{array}$ & $\begin{array}{r}1.40 b \\
(0.14)\end{array}$ & $\begin{array}{r}0.09 \mathrm{a} \\
(0.01)\end{array}$ & $\begin{array}{r}0.10 \mathrm{a} \\
(0.01)\end{array}$ & $\begin{array}{r}0.09 \mathrm{a} \\
(0.01)\end{array}$ & $\begin{array}{r}0.52 \mathrm{a} \\
(0.08)\end{array}$ & $\begin{array}{r}0.43 b \\
(0.07)\end{array}$ & $\begin{array}{l}0.44 b \\
(0.1)\end{array}$ \\
\hline Branchwood 1 year & $\begin{array}{r}1.10 \mathrm{a} \\
(0.15)\end{array}$ & $\begin{array}{r}1.12 \mathrm{a} \\
(0.12)\end{array}$ & $\begin{array}{r}1.14 \mathrm{a} \\
(0.13)\end{array}$ & $\begin{array}{r}0.13 \mathrm{a} \\
(0.02)\end{array}$ & $\begin{array}{r}0.13 a \\
(0.01)\end{array}$ & $\begin{array}{r}0.14 b \\
(0.02)\end{array}$ & $\begin{array}{r}0.56 a \\
(0.08)\end{array}$ & $\begin{array}{r}0.50 b \\
(0.07)\end{array}$ & $\begin{array}{r}0.450 \\
(0.07)\end{array}$ \\
\hline $\begin{array}{l}\text { Branchwood }>1 \\
\text { year }\end{array}$ & $\begin{array}{r}0.43 \mathrm{a} \\
(0.14)\end{array}$ & $\begin{array}{r}0.41 \mathrm{a} \\
(0.15)\end{array}$ & $\begin{array}{r}0.42 \mathrm{a} \\
(0.13)\end{array}$ & $\begin{array}{r}0.05 a \\
(0.16)\end{array}$ & $\begin{array}{r}0.04 a \\
(0.17)\end{array}$ & $\begin{array}{r}0.05 \mathrm{a} \\
(0.02)\end{array}$ & $\begin{array}{r}0.28 b \\
(0.13)\end{array}$ & $\begin{array}{l}0.23 \mathrm{ab} \\
(0.08)\end{array}$ & $\begin{array}{c}0.21 \mathrm{~b} \\
(0.08)\end{array}$ \\
\hline \multicolumn{10}{|l|}{ Stem } \\
\hline Stemwood & $\begin{array}{r}0.069 a \\
(0.005)\end{array}$ & $\begin{array}{r}0.060 \mathrm{~b} \\
(0.003)\end{array}$ & $\begin{array}{r}0.061 \mathrm{~b} \\
(0.004)\end{array}$ & $\begin{array}{r}0.005 a \\
(0.001)\end{array}$ & $\begin{array}{r}0.002 b \\
(0.001)\end{array}$ & $\begin{array}{c}0.003 c \\
(0.0001)\end{array}$ & $\begin{array}{l}0.054 \mathrm{a} \\
(0.01)\end{array}$ & $\begin{array}{r}0.034 b \\
(0.004)\end{array}$ & $\begin{array}{c}0.023 \mathrm{~b} \\
(0.003)\end{array}$ \\
\hline Stembark & $\begin{array}{c}0.57 \mathrm{a} \\
(0.054)\end{array}$ & $\begin{array}{c}0.42 \mathrm{~b} \\
(0.039)\end{array}$ & $\begin{array}{c}0.33 c \\
(0.023)\end{array}$ & $\begin{array}{r}0.067 a \\
(0.007)\end{array}$ & $\begin{array}{r}0.049 b \\
(0.008)\end{array}$ & $\begin{array}{r}0.042 \mathrm{c} \\
(0.006)\end{array}$ & $\begin{array}{r}0.42 \mathrm{a} \\
(0.13)\end{array}$ & $\begin{array}{c}0.27 \mathrm{~b} \\
(0.055)\end{array}$ & $\begin{array}{c}0.22 \mathrm{~b} \\
(0.046)\end{array}$ \\
\hline
\end{tabular}

Different letters indicate significant difference at $P>0.05$.

young needles ( 1 year old) $>$ old needles (older than 1 year) $>$ twigs $>$ old branches $>$ stembark $>$ stemwood. This is true for all elements except $\mathrm{Ca}$ which sometimes had higher concentrations in the old than in the young organs. Some statistically significant differences of concentrations occurred between stands, particularly between the younger and the older stand. The 40year-old stand was similar to the 20-year-old stand as far as canopy components were concerned and similar to the 60 -year-old stand as far as stand components were concerned. Negative relationships between concentrations and dendrometrical parameters (i.e. $D_{10}$ for branches and $C_{130}$ for stem ) supported by total correlation coefficients (matrix not shown) were generally observed for all the observations on the three stands.

For the crown, the coefficient value was lower for needles than for ligneous organs, and in the latter the coefficients were very much higher for the old part of the branches where they are statistically significant at $P<0.001$ (e.g. -0.72 for $\mathrm{N}$, -0.65 for $\mathrm{P},-0.63$ for $\mathrm{K},-0.41$ for $\mathrm{Ca}$ and -0.51 for $\mathrm{Mg}$; 93 observations). No tree effect (relationship between $C_{130}$ and concentration of a component) was observed for the chemical composition of the tree crown.

For the stem (36 observations), the coefficients were statistically significant at the $P<0.001$ level for $\mathrm{K}, \mathrm{Ca}, \mathrm{Mg}, \mathrm{Mn}$ and $\mathrm{S}$ for wood, and for $\mathrm{N}, \mathrm{P}, \mathrm{Mg}, \mathrm{Mn}$ and $\mathrm{S}$ for the bark $(\mathrm{K}, \mathrm{Ca}$ at $P<0.01$ level only). More complex figures occurred for individual stands probably owing to the limited number of observations (12 per stand) and/or smaller spectra for dendrometric parameter variations. The same trend was generally but not systematically observed. Nevertheless, correlations were not strong enough to build accurate provisional models.

\subsection{Quantitative aspect of biomass and nutrient distribution}

Common biomass and nutrient content tables for the three stands were established for each tree component on a quantitative basis. The observed concentration of the sample and its biomass were used for nutrient content data. Some models are presented in Table 5.

Stand biomass (Table 6) is age dependent for stem biomass, which is a strictly cumulative 


\begin{tabular}{|c|c|c|c|c|c|c|c|c|c|c|c|}
\hline \multicolumn{3}{|l|}{$\mathrm{Ca}$} & \multicolumn{3}{|l|}{$\mathbf{M g}$} & \multicolumn{3}{|l|}{$\mathrm{Mn}$} & \multicolumn{3}{|l|}{$S$} \\
\hline 20 years & 40 years & 60 years & 20 years & 40 years & 60 years & 20 years & 40 years & 60 years & 20 years & 40 years & 60 years \\
\hline $\begin{array}{c}0.47 \mathrm{ab} \\
(0.14)\end{array}$ & $\begin{array}{r}0.42 \mathrm{a} \\
(0.12)\end{array}$ & $\begin{array}{r}0.49 \mathrm{~b} \\
(0.09)\end{array}$ & $\begin{array}{r}0.12 \mathrm{a} \\
(0.03)\end{array}$ & $\begin{array}{r}0.12 \mathrm{a} \\
(0.02)\end{array}$ & $\begin{array}{r}0.12 \mathrm{a} \\
(0.02)\end{array}$ & & & & & & \\
\hline $0.75 \mathrm{a}$ & $0.66 \mathrm{a}$ & $0.90 \mathrm{~b}$ & $0.11 \mathrm{a}$ & $0.11 \mathrm{a}$ & $0.12 a$ & & & & & & \\
\hline$(0.31)$ & $(0.21)$ & $(0.21)$ & $(0.03)$ & $(0.03)$ & $(0.03)$ & & & & & & \\
\hline $0.42 a$ & $0.39 a$ & $0.49 b$ & $0.11 \mathrm{a}$ & $0.12 \mathrm{a}$ & $0.11 \mathrm{a}$ & & & & & & \\
\hline$(0.1)$ & $(0.11)$ & $(0.11)$ & $(0.02)$ & $(0.03)$ & $(0.03)$ & & & & & & \\
\hline $\begin{array}{r}0.34 a \\
(0.09)\end{array}$ & $\begin{array}{r}0.32 \mathrm{a} \\
(0.13)\end{array}$ & $\begin{array}{r}0.46 \mathrm{~b} \\
(0.12)\end{array}$ & $\begin{array}{r}0.04 a \\
(0.01)\end{array}$ & $\begin{array}{r}0.04 a \\
(0.01)\end{array}$ & $\begin{array}{r}0.04 a \\
(0.02)\end{array}$ & & & & & & \\
\hline $\begin{array}{r}0.040 \mathrm{a} \\
(0.004)\end{array}$ & $\begin{array}{r}0.028 \mathrm{~b} \\
(0.004)\end{array}$ & $\begin{array}{c}0.029 \mathrm{~b} \\
(0.004)\end{array}$ & $\begin{array}{r}0.007 a \\
(0.001)\end{array}$ & $\begin{array}{c}0.010 \mathrm{a} \\
(0.001)\end{array}$ & $\begin{array}{r}0.005 b \\
(0.006)\end{array}$ & $\begin{array}{r}0.009 \mathrm{a} \\
(0.002)\end{array}$ & $\begin{array}{r}0.008 \mathrm{a} \\
(0.002)\end{array}$ & $\begin{array}{r}0.004 b \\
(0.002)\end{array}$ & $\begin{array}{c}0.01 \mathrm{a} \\
(0.001)\end{array}$ & $\begin{array}{r}0.009 \mathrm{a} \\
(0.002)\end{array}$ & $\begin{array}{r}0.002 \mathrm{~b} \\
(0.001)\end{array}$ \\
\hline $0.370 \mathrm{a}$ & $0.279 \mathrm{a}$ & $0.309 a$ & $0.053 \mathrm{a}$ & $0.038 \mathrm{~b}$ & $0.032 \mathrm{~b}$ & $0.069 a$ & $0.075 a$ & $0.039 a$ & $0.050 \mathrm{a}$ & $0.049 a$ & $0.036 \mathrm{~b}$ \\
\hline$(0.087)$ & $(0.199)$ & $(0.111)$ & $(0.012)$ & $(0.01)$ & $(0.006)$ & $(0.05)$ & $(0.065)$ & $(0.018)$ & $(0.004)$ & $(0.006)$ & $(0.003)$ \\
\hline
\end{tabular}

component, and to a lesser extent for the ligneous part of the crown. Total foliar biomass became more or less stable from age 20 ; this component varied considerably for current needle production: $6.4 \mathrm{t}$ at age 20 vs. $3.8 \mathrm{t}$ at age 40 or 60 which seemed difficult to attribute to the annual variation alone (Fig. 1). A very large increment of stem biomass occurred between 20 and $40(+241 \%)$ and is still large between 40 and 60 $(+57 \%)$. The proportion of stem in the total aerial biomass is the same between the 40 -yearold and the 60-year-old stands (see Fig. 3 ). The mean stem characteristics show that no significant differences are observed between stands for wood and bark infra-density (i.e. dry weight/ fresh volume). The wood percentage slightly but significantly increases with stand age (Table 7).

The distribution of major nutrients in the biomass components is given in Table 6. Fig. 2 shows the behaviour of biomass and nutrient accumulation in the total aerial biomass and in the stem. In the case of total biomass, the maximum accumulation for $\mathrm{Ca}$ and $\mathrm{K}$ tends to be earlier than biomass accumulation, the reverse is observed for $\mathrm{P}$ and $\mathrm{Mg}$, while $\mathrm{N}$ accumulates proportionally to biomass during the whole stand development (Fig. 2(a)). In the case of the stem only, accu- mulation of $\mathrm{N}, \mathrm{K}$ and to a lesser extent $\mathrm{P}$ and $\mathrm{Mg}$ tends to be earlier than biomass accumulation; the reverse tendency occurs for Ca (Fig. 2(b)).

The relative distribution of biomass and nutrients in the various stand components clearly illustrates that tree crown, which represents a limited part of total biomass, retains the largest quantities of all nutrients especially $\mathrm{N}, \mathrm{P}$ and $\mathrm{Ca}$ (Fig. 3). This is particularly true in the young stand; the values are more equally distributed between crown and stem in the 40 -year-old and 60 -year-old stands. The comparison between these two stands shows that for $\mathrm{P}, \mathrm{Ca}$ and $\mathrm{Mg}$, no change occurs in their relative distribution; for $\mathrm{N}$ a slight but significant increase, and for $\mathrm{K}$ a relatively large decrease are observed between 40 and 60 . In the crown, needles contain the greater quantity of elements; in the stem, bark contains almost the same but often larger quantities of nutrients than wood for a biomass representing only $15 \%$ of the total biomass (Table 6 ).

The mean annual production for the stem alone and for the different 'equivalent' stages of the stand is respectively $8.4 \mathrm{~m}^{3} \mathrm{ha}^{-1}$ year $^{-1}$ for the period 0-20 years, $20.8 \mathrm{~m}^{3} \mathrm{ha}^{-1}$ year $^{-1}$ for the period 20-40 years and $17.4 \mathrm{~m}^{3} \mathrm{ha}^{-1}$ year $^{-1}$ for the period $40-60$ years. The mean biomass 
Table 5

Mainbiomass and nutrient content

\begin{tabular}{|c|c|c|c|c|}
\hline Component & Sub-component & Model & $R^{2}$ & RMSE \\
\hline \multicolumn{5}{|l|}{$\begin{array}{l}\text { Main } \\
\text { biomass }^{\mathrm{a}}\end{array}$} \\
\hline \multirow[t]{2}{*}{ Crown } & Total needles & $y=\left(12.7128-0.4237 \times A+0.00408 \times A^{2}\right) \times C_{130^{2}}$ & 0.95 & 9729.3 \\
\hline & Total ligneous branch & $y=\left(0.3424-0.0114 \times A+0.000116 \times A^{2}\right) \times C_{130}{ }^{2,80}$ & 0.95 & 29907.6 \\
\hline \multirow[t]{2}{*}{ Stem } & Stembark & $y=0.0068 C_{130^{2}}-0.0792 \times 1 / A \times C_{130}^{2}$ & 0.99 & 10.3 \\
\hline & Stemwood & $y=0.0468 C_{130^{2}}{ }^{2}-0.5570 \times 1 / .4 \times C_{130^{2}}$ & 0.99 & 68.3 \\
\hline \multicolumn{5}{|c|}{ Main nutrient content $t^{b}$} \\
\hline \multirow[t]{10}{*}{ Crown } & Total needles & $N=\left(0.2052-0.0068 \times A+0.000064 \times A^{2}\right) \times C_{130^{2}}$ & 0.95 & 142.4 \\
\hline & & $P=\left(0.0119-0.0004 \times A+0.000004 \times A^{2}\right) \times C_{130^{2}}$ & 0.95 & 9.6 \\
\hline & & $\mathrm{K}=\left(0.0688-0.0024 \times A+0.000024 \times A^{2}\right) \times C_{130^{2}}$ & 0.95 & 47.6 \\
\hline & & $\mathrm{Ca}=\left(0.1352-0.0051 \times A+0.000053 \times A^{2}\right) \times C_{130^{2}}$ & 0.95 & 77.4 \\
\hline & & $\mathrm{Mg}=\left(0.0137-0.0004 \times A+0.000004 \times A^{2}\right) \times C_{130^{2}}$ & 0.95 & 10.0 \\
\hline & Total ligneous branch & $\mathrm{N}=\left(0.0009+0.6701 \times 1 / A^{2}\right) \times C_{130^{2.5}}$ & 0.95 & 73.1 \\
\hline & & $\mathrm{P}=\left(0.00071-0.000026 \times A+0.0000003 \times A^{2}\right) \times C_{130^{2,5}}$ & 0.95 & 7.7 \\
\hline & & $\mathrm{K}=\left(0.0029-0.00008 \times A+0.0000007 \times A^{2}\right) \times C_{130^{2,5}}$ & 0.95 & 27.6 \\
\hline & & $\mathrm{Ca}=\left(0.0038-01949 \times 1 / A+3.4601 \times 1 / A^{2}\right) \times C_{130}{ }^{2.5}$ & 0.96 & 87.3 \\
\hline & & $\mathrm{Mg}=\left(0.0006-0.00002 \times A+0.0000002 \times A^{2}\right) \times C_{130}^{2.5}$ & 0.95 & 8.2 \\
\hline \multirow[t]{10}{*}{ Stem } & Stembark & $\mathrm{N}=0.0187 C_{130^{2}}+0.0088 \times 1 / A \times C_{130}^{2}$ & 0.99 & 34.9 \\
\hline & & $\mathrm{P}=-0.4163 C_{130} \times 1 / A+0.0024 \times C_{130^{2}}$ & 0.98 & 6.6 \\
\hline & & $\mathrm{K}=0.0171 C_{130^{2}}-0.00008 \times A \times C_{130^{2}}$ & 0.97 & 44.6 \\
\hline & & $\mathrm{Ca}=0.0136 C_{130} \times A-0.0000032 \times A^{2} \times C_{130}{ }^{2}$ & 0.94 & 77.2 \\
\hline & & $\mathrm{Mg}=0.0025 C_{130} \times A-0.00087 \times C_{130}^{2}$ & 0.96 & 6.9 \\
\hline & Stemwood & $\mathrm{N}=0.00072 C_{130^{2}}{ }^{2} A-0.0000055 \times A^{2} \times C_{130^{2}}$ & 0.99 & 37.9 \\
\hline & & $\mathbf{P}=0.000017 C_{130^{2} \times A}$ & 0.96 & 4.2 \\
\hline & & $\mathrm{K}=0.00062 C_{130^{2}}{ }^{2} \times A-0.0000081 \times A^{2} \times C_{130^{2}}$ & 0.96 & 34,3 \\
\hline & & $\mathrm{Ca}=0.014442 C_{130^{2}}{ }^{2}-0.174359 \times 1 / A \times C_{130}^{2}$ & 0.97 & 39.0 \\
\hline & & $\mathrm{Mg}=0.00139 C_{130} \times A-0.001282 \times C_{130}{ }^{2}$ & 0.99 & 4,0 \\
\hline
\end{tabular}

${ }^{\text {a}}$ Data are expressed in grams of dry matter at $65^{\circ} \mathrm{C}$ for crown and in kilograms dry matter for stem.

'Data are expressed in grams of element.

Age in years and $C_{130}$ in centimetres.

immobilisation is smallest for the young stand (4.1 $\mathrm{t} \mathrm{ha}^{-1}$ year $^{-1}$ ) and highest in the 40-yearold stand $\left(8.3 \mathrm{tha}^{-1}\right.$ year $\left.^{-1}\right)$ which is the stage of the maximum mean and current annual increment according to the yield table of Decourt (1967). The young stands immobilise almost the same quantity of nutrients as the older ones which produce twice the biomass. In terms of nutrients, immobilisation represents no more than $40 \%$ of the total uptake. The total litterfall (mainly needles and branchwood) is significantly higher in the younger stand which is in agreement with the general conclusions of Albrektson (1988) on the effect of stand age on litterfall. The formation of the annual crown represents the greatest part of the annual uptake from soil especially for $\mathrm{N}, \mathrm{P}, \mathrm{Ca}$ and $\mathrm{Mg}$ (Table 8).

\section{Discussion}

\subsection{Nutrient distribution in stands}

The general nutrition status of the three stands is at or near optimum for all the major elements if compared with Bonneau's references (1988) (Table 3). Phosphorus appears to be slightly limiting in the mature stands. The 20 -year-old stand shows the highest concentrations of the three stands for all major nutrients. This observation must not necessarily be attributed to a 
Biomass of the component ( $t$ per ha)

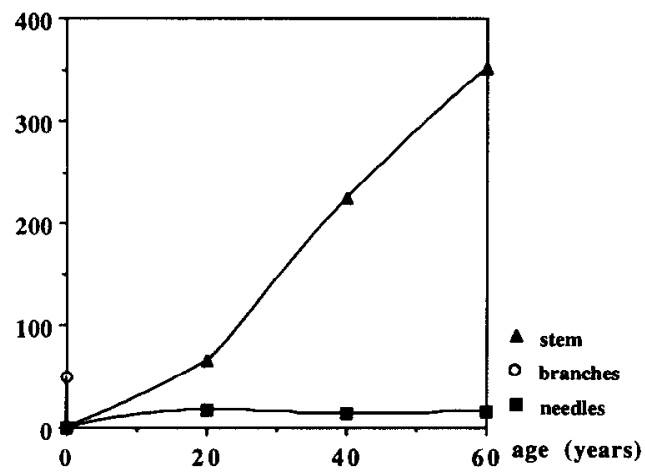

Fig. 1. Dynamics of the stand biomass accumulation according to the component.

greater availability of nutrients in the soil of this stand because it was often observed and described as an effect of youth (Bonneau, 1986).

The general negative correlation observed for the three stands between branch or tree dimension and their nutrient content is linked (i) to the fact that there are relatively more functional tissues in each ligneous component of the younger stand, and (ii) to the strong decrease of nutrient concentrations according to tissue age as shown by Monestier (1993) for the stemwood of these stands. This internal cycle of nutrients is very efficient (Switzer and Nelson, 1972; Huguet and Giraudon, 1979; Titus and Kang, 1980; Ranger, 1981) and allows the forest stand to produce a significant quantity of biomass in soils with limited pools of available nutrients (ColinBelgrand et al., 1993). When this negative relation occurs in a population of trees of the same age it indicates that smaller trees use nutrients less efficiently than bigger ones where a dilution effect tends to decrease the mean concentrations. This observation has already been made (Van den Driessche, 1974). The distribution of nutrients observed in the Douglas-fir stand is quite standard. The smaller components for biomass tend to be the most concentrated in nutrients. This observation is of great consequence for forest conservation management where harvesting of the total biomass will rapidly deplete the efficient pool for tree nutrition.
Ligneous blomass (t per ha) or nutrlent content (kg per ha)

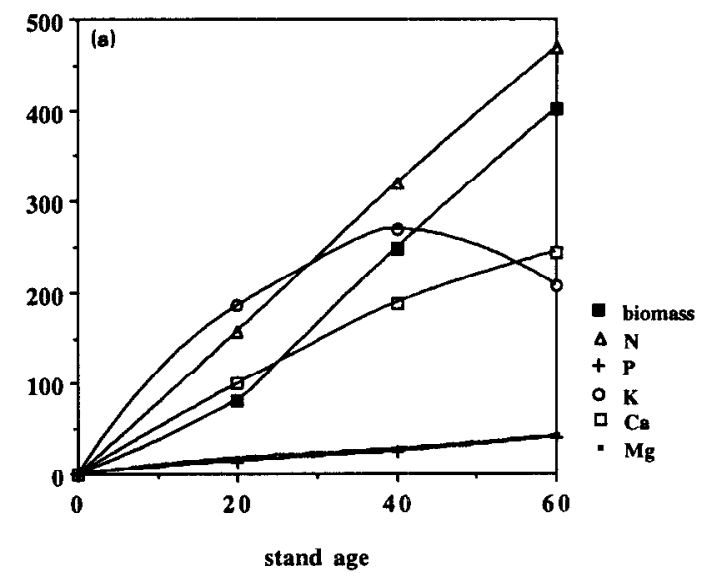

Stem biomass (t per ha) or nutrient content (kg per ha)

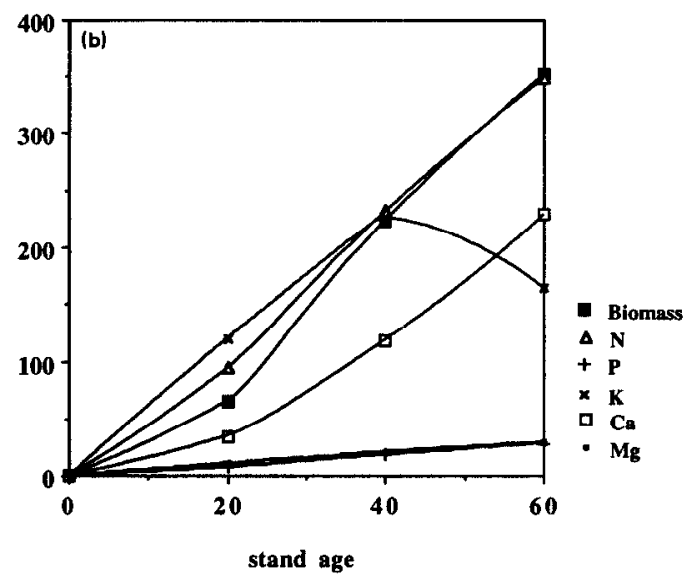

Fig. 2. Dynamics of biomass and nutrient accumulation in the stand for (a) the total ligneous aerial biomass and (b) the stem alone.

\subsection{Nutrient use efficiency for biomass production}

Nutrient use efficiency (NUE) does not refer here to physiological efficiency, which is the nutrients required to build the current increment of a stand. It is an index calculated as the biomass produced by one unit of nutrient during the whole life of a stand. The higher the index, the better the NUE.

NUE tends to increase with stand age for all 
Table 6

Biomass $\left(\mathrm{tha}^{-1}\right)$ and mineral content $\left(\mathrm{kg} \mathrm{ha}^{-1}\right)$ per component and per stand

\begin{tabular}{|c|c|c|c|c|c|c|c|c|c|c|c|}
\hline & \multicolumn{8}{|l|}{20 years } & \multicolumn{3}{|l|}{40 years } \\
\hline & Biomass & $\mathrm{N}$ & $\mathrm{P}$ & $\mathrm{K}$ & $\mathrm{Ca}$ & $\mathrm{Mg}$ & $\mathrm{Mn}$ & $\mathrm{s}$ & Biomass & $\mathrm{i}$ & P \\
\hline \multicolumn{12}{|l|}{ Tree crown } \\
\hline Needles 1 year & 6.4 & 102.6 & 7.0 & 37.2 & 30.1 & 7.7 & & & 3.8 & 61.7 & +1 \\
\hline Needles $>1$ year & 11.7 & 141.6 & 8.0 & 42.3 & 96.6 & 9.6 & & & 9.5 & 1411 & 8.5 \\
\hline Total needles & 17.4 & 286.9 & 17.0 & 83 & 162 & 19.3 & & & 13.6 & 209.8 & 13.5 \\
\hline Branchwood 1 year & 1.5 & 16.6 & 2.0 & 8.5 & 6.3 & 1.7 & & & 0.9 & 10.0 & 1.2 \\
\hline Branchwood > year & 14.5 & 56.8 & 5.9 & 38.4 & 54.4 & 5.9 & & & 21.9 & 72.5 & 7.1 \\
\hline Total branchwood & 16.8 & 63.2 & 7.3 & 35.9 & 65.2 & 7.3 & & & 25.0 & 87.8 & 7,2 \\
\hline Total crown & 34.2 & 350.1 & 24.3 & 118.9 & 227.2 & 26.6 & & & 38.6 & 297.6 & 20.7 \\
\hline \multicolumn{12}{|l|}{ Stem } \\
\hline stemwood & 56.9 & 36.9 & 1.0 & 73.5 & 17.1 & 5.3 & 5.4 & 4.9 & 194.8 & 1190 & 4.1 \\
\hline Stembark & 8.6 & 57.3 & 6.2 & 46.1 & 17.7 & 5.1 & 8.2 & 4.6 & 28.7 & 111.9 & 13.0 \\
\hline Total stem & 65.5 & 94.2 & 7.2 & 119.6 & 34.8 & 10.4 & 13.6 & 9.5 & 223.5 & 231.8 & 18.0 \\
\hline Total ligneous & 82.3 & 157.4 & 14.5 & 155.5 & 100.0 & 17.7 & & & 248.5 & 319.6 & 25.2 \\
\hline Total tree aerial & 99.7 & 444.3 & 31.5 & 238.5 & 262.0 & 37.0 & & & 262.1 & 529.4 & 38.7 \\
\hline
\end{tabular}

\section{(Continued)}

\begin{tabular}{|c|c|c|c|c|c|c|c|c|c|c|c|c|}
\hline \multicolumn{5}{|c|}{40 years } & \multicolumn{8}{|l|}{60 years } \\
\hline $\mathrm{K}$ & $\mathrm{Ca}$ & $\mathrm{Mg}$ & $\mathrm{Mn}$ & $\mathrm{S}$ & Biomass & $\mathrm{N}$ & $\mathbf{P}$ & $\mathrm{K}$ & $\mathrm{Ca}$ & $\mathrm{Mg}$ & $\mathrm{Mn}$ & $S$ \\
\hline 19.9 & 15.8 & 4.5 & & & 3.8 & 57.3 & 4.5 & 19.2 & 18.5 & 4.5 & & \\
\hline 37 & 59 & 9.3 & & & 10.4 & 167.4 & 10.3 & 58.1 & 117.0 & 11.6 & & \\
\hline 60.9 & 80.7 & 14.6 & & & 16.1 & 224.6 & 16.3 & 79.3 & 129.0 & 16.0 & & \\
\hline 4.5 & 3.5 & 1.1 & & & 0.9 & 9.7 & 1.2 & 3.8 & 4.2 & 0.9 & & \\
\hline 45.8 & 63.6 & 7.5 & & & 45.6 & 115.9 & 11.2 & 47.8 & 157.4 & 13.2 & & \\
\hline 43.1 & 70 & 7.2 & & & 49.7 & 120.8 & 13.3 & 43.7 & 162.3 & 13.3 & & \\
\hline 104 & 150.7 & 21.8 & & & 65.8 & 345.4 & 29.6 & 123 & 291.3 & 29.3 & & \\
\hline 145.9 & 59.5 & 10.5 & 14.1 & 16.6 & 307.0 & 194.6 & 8.5 & 65.5 & 94.1 & 14.6 & 13.8 & 6.7 \\
\hline 81.2 & 59.1 & 10.3 & 14.9 & 13.6 & 45.0 & 153.9 & 19.6 & 98.5 & 134.8 & 14.4 & 16.3 & 15.9 \\
\hline 227.1 & 118.6 & 20.8 & 29.0 & 30.2 & 352.0 & 348.5 & 28.1 & 164.0 & 228.9 & 29.0 & 30.1 & 22.6 \\
\hline 270.2 & 188.6 & 28.0 & & & 401.7 & 469.3 & 41.4 & 207.7 & 391.2 & 42.3 & & \\
\hline 331.1 & 269.3 & 42.6 & & & 417.8 & 693.9 & 57.7 & 287.0 & 520.2 & 58.3 & & \\
\hline
\end{tabular}


Table 7

Wood characteristics (mean $\pm \mathrm{SD}, n=12$ )

\begin{tabular}{cccc}
\hline & \multicolumn{3}{l}{ Stand age (years) } \\
\cline { 2 - 4 } & 20 & 40 & 60 \\
\hline Wood density & $0.40 \mathrm{a}$ & $0.39 \mathrm{a}$ & $0.38 \mathrm{a}$ \\
$\left(\mathrm{g} \mathrm{cm}^{-3}\right)$ & \pm 0.03 & \pm 0.03 & \pm 0.03 \\
Bark density & $0.34 \mathrm{a}$ & $0.34 \mathrm{a}$ & $0.31 \mathrm{a}$ \\
$\left(\mathrm{g} \mathrm{cm}^{-3}\right)$ & \pm 0.08 & \pm 0.04 & \pm 0.07 \\
Wood & $85.6 \mathrm{a}$ & $86.8 \mathrm{ab}$ & $87.3 \mathrm{~b}$ \\
percentage & \pm 1.9 & \pm 1.6 & \pm 1.4 \\
\hline
\end{tabular}

Different letters between stands indicate significant difference at the $95 \%$ level of confidence.

elements. This observation seems to be true for other sequences found in the literature concerning the same species (Turner and Long, 1975; Turner, 1981) or other species like Norway spruce (Le Goaster et al., 1991) with sometimes an exception for $\mathrm{Ca}$ (Table 9). The result is the same whatever the ligneous component considered. The most evident explanation is that the proportion of heartwood increases with stand age. This component contains much lower concentrations than active sapwood due to internal translocation of nutrients (Switzer and Nelson, 1972; Colin-Belgrand et al., 1993). Comparison between age sequences of Douglas-fir shows that the interaction between provenances and/or ecological situations has a considerable effect on this index.

There is great interest in comparing NUE values for Douglas-fir and Norway spruce as both of these species are widely used in France for afforestation, under the same ecological conditions (Table 9). As direct comparison is not possible on this site, it was not possible to draw any definite conclusions, but only to show tendencies. The data show a greater efficiency for Douglas-fir when compared with Norway spruce for a comparable stand age for $\mathrm{N}, \mathrm{Ca}$ and $\mathrm{Mg}$, independently of the ecological situation; the tendency is not so clear for $P$ and $K$ with no visible difference between the two species.

\subsection{Uptake of nutrients by stands}

Comparison with the mean annual uptake of coniferous species from the IPB sites (Cole,
1986) shows that adult Douglas-fir stands are almost situated at the mean or under the mean (studied stands) for all major nutrients (Table 10). The annual uptake of Douglas-fir is not higher than Norway spruce especially if it is compared with a stand of similar productivity (Ranger et al., 1992). Nutrient uptake tends to decrease with stand age. This phenomenon is controlled by three main parameters: (i) the decrease of foliar biomass with age well correlated with litterfall; (ii) the variation of the current annual stand increment; (iii) the decrease of nutrient immobilisation rate with stand age according to the 'dilution effect' linked to cumulative growth.

\subsection{Predictable effect of the decrease of the rotation length on nutrient removal by harvesting}

The total drain of nutrients from a site corresponds to nutrient removal with crop harvesting and to the losses associated to the deep drainage flux out of the rooting zone, during rotation and the harvest phase and regeneration. Ranger and Nys (1986) found that deep drainage during the rotation represents approximately the same amount of nutrients than the harvest (except for $P$ generally not mobile in soil solutions). Only nutrient removal by harvesting was considered here. Stands were compared for a 120 year period which are two, three and six rotations for the 60-year-old, 40-year-old and 20-year-old stands respectively. Two intensities of harvesting were considered: (i) a partial harvest of the stand biomass, i.e. stem-only harvest; (ii) wholetree harvest including needles, which are obligatorily removed on coniferous trees if branches are harvested (this figure occurs if branches are removed in some special places of the forest for technical reasons) (Table 11). These figures represent conservative and intensive scenarios for nutrient conservation.

\subsubsection{The case of timber harvest}

The decrease of the rotation length from 60 to 40 years slightly decreased the collected biomass $(-0.8 \%)$ with no dramatic consequences on nu- 

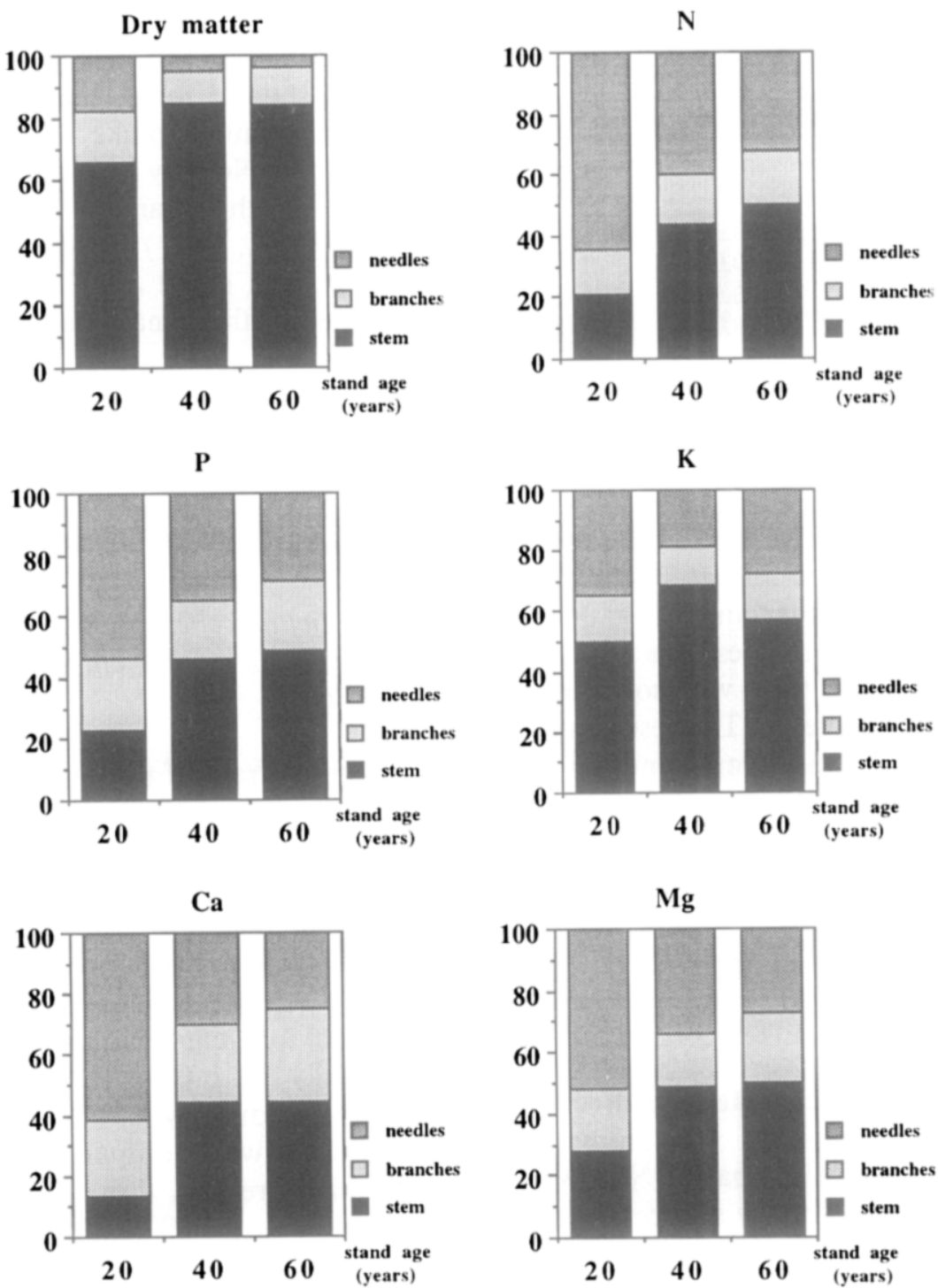

Fig. 3. Relative distribution of biomass and nutrients in the stand according to its stage of development.

trient removal except for $\mathrm{K}$; i.e. $\mathrm{N}$ and $\mathrm{P}$ remain more or less stable, $\mathrm{Ca}$ decreased $(-17 \%), \mathrm{K}$ and $\mathrm{Mg}$ increased ( $+96 \%$ for $\mathrm{K}$ ). The decrease of the rotation length from 60 to 20 years produced more important effects. The biomass decreased by $51 \%$ without a proportional decrease for the majority of nutrients (except for $\mathrm{Ca}$ ) and a severe increase for $K(+82 \%)$. The decrease of the rotation length from 40 to 20 years produced approximately the same effect as before except for $\mathrm{K}$. Thinnings represented $14 \%$ of the biomass and between 15 and $20 \%$ of the nutrients according to elements in the standing crop for the 60-yearold stand and $19 \%$ of the biomass and between 15 and $30 \%$ of the nutrients in the 40 -year-old stand.

\subsubsection{The case of whole-tree harvest}

The decrease in the rotation length led to the same relative conclusions as those found for timber harvest. A more drastic effect on soil nutrient removal occurred for the decrease from 60 
Table 8

Evaluation of the mean annual uptake as a function of stand age

\begin{tabular}{|c|c|c|c|c|c|c|c|}
\hline $\begin{array}{l}\text { Stand age } \\
\text { (years) }\end{array}$ & & $\begin{array}{l}\text { Dry matter } \\
\left(\mathrm{t} \mathrm{ha}^{-1} \text { year }^{-1}\right)\end{array}$ & $\begin{array}{l}\mathrm{N}\left(\mathrm{kg} \mathrm{ha}^{-1}\right. \\
\left.\text { year }^{-1}\right)\end{array}$ & $\begin{array}{l}\mathrm{P}(\mathrm{kg} \mathrm{ha} \\
\left.\text { year }^{-1}\right)\end{array}$ & $\begin{array}{l}\mathrm{K}\left(\mathrm{kg} \mathrm{ha} \mathrm{a}^{-1}\right. \\
\text { year }\end{array}$ & $\begin{array}{l}\mathrm{Ca}(\mathrm{kg} \mathrm{ha} \\
\left.\text { year }^{-1}\right)\end{array}$ & $\begin{array}{l}\mathrm{Mg}\left(\mathrm{kg} \mathrm{ha}^{-1}\right. \\
\left.\text { year }^{-1}\right)\end{array}$ \\
\hline \multirow[t]{3}{*}{20} & Immobilisation $^{\mathrm{a}}$ & 4.1 & 7.9 & 0.7 & 7.8 & 5.0 & 0.9 \\
\hline & Litterfall $^{b}$ & 3.4 & 35.9 & 3.4 & 4.1 & 24.8 & 3.0 \\
\hline & Uptake $^{c}$ & 7.5 & 43.8 & 4.1 & $19.0^{\mathrm{d}}$ & 29.8 & 3.9 \\
\hline \multirow[t]{3}{*}{40} & Immobilisation & 8.3 & 8.1 & 0.5 & 5.7 & 4.4 & 0.5 \\
\hline & Litterfall & 2.0 & 19.9 & 1.2 & 2.9 & 10.0 & 1.0 \\
\hline & Uptake & 10.3 & 28.0 & 1.7 & $14.0^{\mathrm{d}}$ & 14.5 & 1.5 \\
\hline \multirow[t]{3}{*}{60} & Immobilisation & 7.7 & 7.5 & 0.8 & -3.1 & 10.1 & 0.7 \\
\hline & Litterfall & 2.4 & 23.6 & 1.7 & 5.1 & 13.6 & 1.4 \\
\hline & Uptake & 10.0 & 31.1 & 2.5 & $8.0^{\mathrm{d}}$ & 23.7 & 2.1 \\
\hline
\end{tabular}

${ }^{\text {a}}$ Calculated from total ligneous biomass and nutrient content of the stand, for the periods $0-20,20-40$ and $40-60$ years.

beasured for the year 1992-1993 (May 1992-May 1993).

${ }^{\mathrm{c}}$ Uptake $=$ Immobilization + Restitution (litterfall + crown leaching).

${ }^{d}$ Crown leaching was considered as nil except for $\mathrm{K}$; evaluated from throughfall composition (data not presented).

Table 9

Compared nutrient efficiency for biomass production for Douglas-fir and Norway spruce according to stand age

\begin{tabular}{|c|c|c|c|c|c|c|c|c|c|c|c|c|c|}
\hline & & $\begin{array}{l}\text { Total } \\
\text { stem } \\
\text { biomass }\end{array}$ & $\mathbf{N}$ & $\mathbf{P}$ & $\mathbf{K}$ & $\mathrm{Ca}$ & $\mathrm{Mg}$ & $\begin{array}{l}\text { Total } \\
\text { ligneous } \\
\text { biomass }\end{array}$ & $\mathrm{N}$ & $\mathbf{P}$ & K & $\mathrm{Ca}$ & $\mathrm{Mg}$ \\
\hline Douglas-fir 20 years & & 65.5 & 94.20 & 7.20 & 119.60 & 34.80 & 10.40 & 82.30 & 157.40 & 14.50 & 155.50 & 100.00 & 17.70 \\
\hline present study & Efficiency & & 0.7 & 9.1 & 0.55 & 1.88 & 6.30 & & 0.52 & 5.68 & 0.53 & 0.82 & 4.65 \\
\hline Douglas-fir 40 years & & 223.5 & 231.80 & 18.00 & 227.10 & 118.60 & 20.80 & 248.50 & 319.60 & 25.20 & 270.20 & 188.60 & 28.00 \\
\hline present study & Efficiency & & 0.96 & 12.42 & 0.98 & 1.88 & 10.75 & & 0.78 & 9.86 & 0.92 & 1.32 & 8.88 \\
\hline Douglas-fir 60 years & & 352.0 & 348.50 & 28.10 & 164.00 & 228.90 & 29.00 & 401.70 & 469.30 & 41.10 & 207.70 & 391.20 & 42.30 \\
\hline present study & Efficiency & & 1.01 & 12.53 & 2.15 & 1.54 & 12.14 & & 0.86 & & 1.93 & & 9.50 \\
\hline Douglas-fir 22 years & & 113.3 & 145.00 & 18.30 & 48.00 & 141.00 & 15.30 & 126.50 & 162.00 & 25.30 & 88.00 & 175.00 & 23.20 \\
\hline Turner, 1981 & Efficiency & & 0.78 & 6.19 & 2.36 & 0.80 & 7.41 & & 0.78 & 5.00 & 1.44 & 0.72 & 5.45 \\
\hline Douglas-fir 42 years & & 206.2 & 169.00 & 24.10 & 107.00 & 24.00 & 31.10 & 229.50 & 218.00 & 33.40 & 135.00 & 285.00 & 38.50 \\
\hline Turne & Efficiency & & 1.22 & 8.56 & 1.93 & 0.96 & 6.63 & & 1.05 & 6.87 & 1.70 & 0.81 & 5.96 \\
\hline Dougl & & 267.3 & 174.00 & 24.50 & 217.00 & 246.00 & 36.80 & 293.60 & 236.00 & 30.30 & 277.00 & 318.00 & 44.20 \\
\hline Turner, 1981 & Efficiency & & 1.54 & 10.91 & 1.23 & 1.09 & 7.26 & & 1.24 & 9.69 & 1.06 & 0.92 & 6.64 \\
\hline Norway spruce 30 years & & 93.6 & 119.30 & 12.60 & 91.20 & 112.40 & 14.90 & 121.80 & 260.20 & 29.00 & 154.50 & 189.60 & 25.00 \\
\hline Le Goaster et al., 1991 & Efficiency & & 0.78 & 7.43 & 1.03 & 0.83 & 6.28 & & 0.47 & 4.20 & 0.79 & 0.64 & 4.87 \\
\hline Norway spruce 45 years & & 126.0 & 135.20 & 4.40 & 69.30 & 146.20 & 19.80 & 161.20 & 263.00 & 16.70 & 110.20 & 216.30 & 29.50 \\
\hline Nys et al., 1992 & Efficiency & & 0.93 & 28.64 & 1.82 & 0.86 & 6.36 & & 0.61 & 9.65 & 1.46 & 0.75 & 5.46 \\
\hline Norway spruce 85 years & & 359.4 & 302.80 & 27.20 & 145.80 & 370.90 & 60.50 & 407.30 & 577.30 & 92.50 & 269.90 & 548.40 & 124.60 \\
\hline al., 1992 & Efficiency & & 1.19 & 13.21 & 2.47 & 0.97 & 5.94 & & 0.71 & 4.40 & 1.51 & 0.74 & 3.27 \\
\hline Norw & & 234.1 & 277.80 & 11.80 & 145.40 & 311.70 & 33.20 & 260.80 & 352.50 & 19.60 & 184.80 & 396.70 & 40.20 \\
\hline Le Goaster et al., 1991 & Efficiency & & 0.84 & 19.84 & 1.61 & 0.75 & 7.05 & & 0.74 & 13.31 & 1.41 & 0.66 & 6.49 \\
\hline
\end{tabular}

Biomass is expressed in $\mathrm{t} \mathrm{ha}^{-1}$; nutrients in $\mathrm{kg} \mathrm{ha}^{-1}$.

to 20 years rotation than from 60 to 40 . This observation can be related to the fact that the proportion of stem in the total aerial biomass is the same between the 40 -year-old and the 60 -yearold stands. A different pattern was described for an age series of Norway spruce stands by Le
Goaster et al. (1991), possibly related to the different rate of development of the two species and/or silvicultural practices.

Thinnings represented $6 \%$ of the biomass and less than $10 \%$ of the nutrients for all elements in 
Table 10

Comparison between the uptake of Douglas-fir and Norway spruce (data in $\mathrm{kg} \mathrm{ha}^{-1} \mathrm{year}^{-1}$ )

\begin{tabular}{|c|c|c|c|c|c|c|c|}
\hline Species & Age (years) & & $\mathrm{N}$ & $\mathrm{P}$ & $\mathrm{K}$ & $\mathrm{Ca}$ & $\mathrm{Mg}$ \\
\hline Conifers & Mean IBP sites & Cole $(1986)$ & 39.0 & 5.0 & 25.0 & 35.0 & 6.0 \\
\hline Douglas-fir & 20 & Present study & 43.8 & 4.1 & 19.0 & 29.8 & 3.9 \\
\hline Douglas-fir & 40 & Present study & 28.0 & 1.7 & 14.0 & 14.5 & 1.5 \\
\hline Douglas-fir & 60 & Present study & 31.1 & 2.5 & 8.0 & 23.7 & 2.1 \\
\hline Douglas-fir & 22 & Cole (1986) & 33.7 & ND & 26.3 & 34.4 & ND \\
\hline Douglas-fir & 42 & Cole $(1986)$ & 32.8 & ND & 27.4 & 40.9 & ND \\
\hline Douglas-fir & 73 & Cole $(1986)$ & 32.5 & ND & 21.4 & 432 & ND \\
\hline Norway spruce & 30 & Le Goaster et al. (1991) & 31.6 & 3.1 & 30.0 & 17.1 & 32 \\
\hline Norway spruce & 85 & Le Goaster et al. (1991) & 24.4 & 2.3 & 25.0 & 8.8 & 10 \\
\hline Norway spruce & 45 & Nys et al. (1983) & 70.8 & 5.6 & 37.3 & 26.9 & 4.7 \\
\hline Norway spruce & 85 & Ranger et al. (1992) & 72.0 & 4.9 & 23.6 & 24.1 & 4.4 \\
\hline
\end{tabular}

the standing crop for both the 40 and 60 -year-old stands.

The comparison between the timber-harvest only and the whole-tree harvest showed a significant increase in biomass collected $52 \%, 18 \%$ and $20 \%$ for the 20 -year-old, 40 -year-old and 60 -yearold stands, respectively (see comparison between crop intensities in Table 11 ). The removal of nutrients increased in general in a very much greater proportion especially for $\mathrm{N}, \mathrm{P}, \mathrm{Ca}$ and $\mathrm{Mg}$. The increase for $\mathrm{Ca}$, i.e. $+650 \%$, in the 20 year rotation-length scenario was the most extreme.

From an ecological point of view, the decrease in the forest rotation length has a clear negative effect on soil nutrients especially if the intensity of the harvest increases at the same time. These conclusions are in agreement with the previous works of Switzer and Nelson (1972), Wells and Jorgensen (1979), Tritton et al. (1987) and Mann et al. (1988). If one takes into account the economic parameters, the increase in the commercial value of Douglas-fir with the size of products rules out the practice of very short rotations.

\section{Conclusion}

The chronosequence of stands is a useful tool to rapidly obtain pertinent information on ecosystem functioning. The three stands selected for this study provide relevant information for accumulation of biomass and nutrient by Douglasfir stands in the principal area in France where this species was intensively introduced. Nevertheless, owing to the limited number of stands the results obtained only provide tendencies as: (i) no replicates were available for observation of intra-age variability; (ii) the use of a chronosequence of stands did not allow one to identify the exact relationship between a property (here production and nutrient storage) and time; (iii) no direct generalisation is possible for other ecological situations (inter-sites variability). The efficiency of Douglas-fir is at least the same as Norway spruce. This important conclusion which needs to be confirmed by other measurements, shows that the uptake of Douglas-fir will not decrease the available pool of soil nutrients more than spruce for the same level of production.

Intensification of forest harvest will inevitably lead to soil impoverishment. The present results obtained on a sequence of stands make it possible to evaluate nutrient losses during harvest with 
Table 11

Effect of rotation length and harvesting intensities on nutrient losses from the site

\begin{tabular}{|c|c|c|c|c|c|c|c|c|c|}
\hline & $\begin{array}{l}\text { Stand age } \\
\text { (years) }\end{array}$ & $\begin{array}{l}\text { Duratioin } \\
\text { (years) }\end{array}$ & Scenario & Biomass & $\mathrm{N}$ & $\mathrm{P}$ & $\mathbf{K}$ & $\mathrm{Ca}$ & $\mathrm{Mg}$ \\
\hline \multirow{12}{*}{$\begin{array}{l}\text { Stem-only } \\
\text { harvesting }\end{array}$} & \multirow[t]{3}{*}{60} & & Standing crop & 352.0 & 348.5 & 28.1 & 164.0 & 228.9 & 29.0 \\
\hline & & & Thinnings & 49.0 & 53.9 & 4.6 & 33.1 & 33.5 & 5.6 \\
\hline & & 120 & 2 harvests (1a) & 802.0 & 804.8 & 65.4 & 394.2 & 524.8 & 69.2 \\
\hline & \multirow[t]{4}{*}{40} & & Standing crop & 223.5 & 231.8 & 18.0 & 227.1 & 118.6 & 20.8 \\
\hline & & & Thinnings & 41.7 & 47.2 & 3.8 & 30.2 & 27.3 & 5.7 \\
\hline & & 120 & 3 harvests ( $2 a)$ & 795.6 & 837.0 & 65.4 & 771.9 & 437.7 & 79.5 \\
\hline & & & $A(2-1) / 1 \%$ & -0.8 & 4.0 & 0.0 & 95.8 & -16.6 & 14.9 \\
\hline & \multirow[t]{5}{*}{20} & & Standing crop & 65.5 & 94.2 & 7.2 & 119.6 & 34.8 & 10.4 \\
\hline & & & Thinnings & 0.0 & 0.0 & 0.0 & 0.0 & 0.0 & 0.0 \\
\hline & & 120 & 6 harvests (3a) & 393.0 & 565.2 & 43.2 & 717.6 & 208.8 & 62.4 \\
\hline & & & $\Delta(3-1) / 1 \%$ & -51.0 & -29.8 & -33.9 & 82.0 & -60.2 & -9.8 \\
\hline & & & $\Delta(3-2) / 2 \%$ & -50.6 & -32.5 & -33.9 & -7.0 & -52.3 & -21.5 \\
\hline \multirow[t]{12}{*}{ Total biomass } & \multirow[t]{3}{*}{60} & & Standing crop & 417.8 & 693.9 & 57.7 & 287 & 520.2 & 58.3 \\
\hline & & & Thinnings & 62.0 & 156.5 & 13.3 & 57.7 & 128.1 & 13.8 \\
\hline & & 120 & 2 harvests $(1 \mathrm{~b})$ & 959.6 & 1700.8 & 142.0 & 689.4 & 1296.6 & 144.2 \\
\hline & \multirow[t]{4}{*}{40} & & Standing crop & 262.1 & 529.4 & 38.7 & 331.1 & 269.3 & 42.6 \\
\hline & & & Thinnings & 51.8 & 135.0 & 10.7 & 48.5 & 98.3 & 13.3 \\
\hline & & 120 & 3 harvests $(2 b)$ & 941.7 & 1993.2 & 148.2 & 1138.8 & 1102.8 & 167.7 \\
\hline & & & $\Delta(2-1) / 1 \%$ & -1.9 & 17.2 & 4.4 & 65.2 & -14.9 & 16.3 \\
\hline & \multirow[t]{5}{*}{20} & & Standing crop & 99.7 & 443.3 & 31.5 & 238.5 & 262.0 & 37.0 \\
\hline & & & Thinnings & 0.0 & 0.0 & 0.0 & 0.0 & 0.0 & 0.0 \\
\hline & & 120 & 6 harvests $(3 b)$ & 598.2 & 2659.8 & 189.0 & 1431.0 & 1572.0 & 222.0 \\
\hline & & & $\Delta(3-1) / 1 \%$ & -37.7 & 56.4 & 33.1 & 107.6 & 21.2 & 53.9 \\
\hline & & & $A(3-2) / 2 \%$ & -36.5 & 33.4 & 27.5 & 25.6 & 42.5 & 32.4 \\
\hline \multirow{3}{*}{$\begin{array}{l}\text { Comparison } \\
\text { between crop } \\
\text { intensities }\end{array}$} & \multicolumn{2}{|l|}{60} & $\Delta(1 \mathrm{~b}-1 \mathrm{a}) / 1 \mathrm{a} \%$ & 19.6 & 111.3 & 117.1 & 74.9 & 147.1 & 108.4 \\
\hline & \multicolumn{2}{|l|}{40} & $\Delta(2 \mathrm{~b}-2 \mathrm{a}) / 2 \mathrm{a} \%$ & 18.4 & 138.1 & 126.6 & 47.5 & 151.9 & 110.9 \\
\hline & \multicolumn{2}{|l|}{20} & $\Delta(3 \mathrm{~b}-3 \mathrm{a}) / 3 \mathrm{a} \%$ & 52.2 & 370.6 & 337.5 & 99.4 & 652.9 & 255.8 \\
\hline
\end{tabular}

Biomass data is expressed in $\mathrm{t} \mathrm{ha}^{-1}$; nutrients in $\mathrm{kg} \mathrm{ha}^{-1}$.

reasonable accuracy. Several scenarios could be drawn using various rotation lengths and harvesting intensities. These results could be introduced in management models. Nevertheless, the direct relationship between nutrient losses and immediate or delayed decrease of forest productivity is not easy to predict. It will depend more on soil nutrient dynamics than on the present available nutrient pool. A conservative recommendation to managers would be to restrict the more intensive treatments to the more fertile soils to ensure the perenniality of the production or to add fertilisers to compensate for the deficit.

The input-output budgets for the whole rotation will provide useful information, especially concerning the most accurate quantity of fertil- isers both for the sustainability of the production and the conservation of the major parameters of the environment, i.e. the soil and the superficial waters.

\section{Acknowledgements}

We would like to thank the following: the technical staff of the 'Cycles biogeochimiques' research team for assistance, the forest managers, l'Office National des Forêts, and particularly G. Poly and B. Jobard for providing all facilities during investigation and sampling, the Ministry of Agriculture, Division de l'Espace Rural et de la Forêt, for providing the financial support for 


\section{this research project and Christine Young for re- vising the English.}

\section{References}

Albrektson, A., 1988. Needle litterfall in stands of Pinus sylvestris $\mathrm{L}$. in Sweden, in relation to site quality, stand age and latitude. Scand. J. For. Res., 3: 33-342.

Bonneau, M., 1986. Diagnostic foliaire. Cours ronéoté, ENGREF, $58 \mathrm{pp}$.

Bonneau, M., 1988. Le diagnostic foliaire. RFF, XL, No. spécial: 19-28.

Bouchon, J., 1982. Potentialités du Douglas (Pseudotsuga menziesii) en France. C.R. Acad. Agric., 6: 441-449.

Bouchon, J., Nys, C. and Ranger, J., 1985. Cubage, biomasse et minéralomasse. Comparaison de trois taillis simples des Ardennes primaires. Acta Oecol. Oecol., Plant., 6 (20, 1$)$ : 53-72.

Burger, J.A. and Powers, R.F., 1991. Field designs for testing hypotheses in long-term site productivity studies. In: W.J. Dyck and C.A. Mees (Editors), Proc. of IAE/BE T6/A6 Workshop on Long-term Trials to Assess Environmental Impacts of Harvesting, Amelia Island, FL, February 1990. FRI Bull. No. 161, For. Inst. Rotorua, NZ, pp. 79-105.

Cole, D.W., 1986. Nutrient cycle in world forests. In: S.P. Gessel (Editor), Forest Site and Productivity. Martinus Nijhoff, Dordrecht, Chap. 9, pp. 104-115.

Cole, D.W. and van Miegroet, H., 1989. Chronosequences: A technique to assess ecosystem dynamics. In: W.I. Dyck and C.A. Mees (Editors). Research Strategies for Longterm Site Productivity, Proc. IAE/BE A3 Workshop, Seattle, WA, August 1988, FRI Bull. No. 152. For. Inst. Rotorua, NZ, pp. 5-24.

Colin-Belgrand, M., Ranger, J. and d'Argouges, S., 1993. Transferts internes d'éléments nutritifs dans le bois de châtaignier (Castanea sativa Miller): approche dynamique sur une chronoséquence de peuplements. I. Distribution des éléments minéraux dans une série de peuplements d'âge croissant. Acta Oecol., 14, 5: 653-680

Decourt, N., 1967. Le Douglas dans le Nord-Est du Massif Central. Ann. Sci. For., 24 (1): 45-84.

Flammang, N., 1992. Biomasse et Minéralomasse de Peuplements de Douglas d'Âge Croissant. DESS ISIAL, Nancy, I, $50 \mathrm{pp}$.

Huguet, J.G. and Giraudon, J., 1979. Redistribution des réserves minérales du prunier d'Ente au printemps, en absence d'absorption racinaire. Colloque Diagnostic Foliaire (C.N.R.F.) document INRA Station d'Agronomie de Bordeaux, pp. 2-9.

Le Goaster, S., Dambrine, E. and Ranger, J., 1991. Croissance et nutrition minérale d'un peuplement d'épicéa sur sol pauvre. I. Évolution de la biomasse et dynamique d'incorporation d'éléments minéraux. Acta Oecol. Oecol., Plant., 12 (6): 771-789.
Mann, L.K., Johnson, D.W., West, D.C., Cole, D.W., Hornbeck J.W., Martin, C.W., Riebeck, H., Smith, C.T., Swank, W.T., Tritton, L.M. and van Lear, D.H., 1988. Effects of whole-tree and stem-only clearcutting on postharvest hydrologic losses, nutrient capital and regrowth. For. Sci. 34 (2): $412-428$.

Monestier, M., 1993: Modélisation de la distribution des été. ments nutritifs majeurs dans le bois de troncs de Douglas (Pseudotsuga menziesii Franco). Approche dynamique sur une chronoséquence de peuplements. D.E.S.S. d'lngénierie Mathématique et d'Outils Informatiques, Nancy. I, 85 pp.

Nys, C., Ranger, D., Ranger, I., 1983. Elude Comparative de deux écosystémes forestiers feuillus et résineux des $\mathrm{Ar}$. dennes primaires françaises. II Mineralomasse et cycle biologique. Ann. Sci. For., 1: 41-66.

Ranger, J., 1981. Etude de la minéralomasse et du cycle biologique dans deux peuplements de Pin Laricio de Corse, dont l'un a été fertilisé à la plantation. Ann. Sci. For., 38 (1): 127-158.

Ranger, J. and Bonneau, M., 1984. Effets prévisibles de l'intensification de la production et des récoltes sur la fertiité des sols de forêt. Le cycle biologique en forêt. Rev. For, Fr., XXXVI (2): 93-112

Ranger, J. and Nys, C.. 1986. Etude des éléments minéraux dans un taillis des Ardennes (Nord de la France): bilan pour une rotation complète. Acta Oecol. Oecol, Plant. 7 $(21,3): 287-305$.

Ranger, J., Cuirin, G., Bouchon, J., Colin-Belgrand, M., Gelhaye, D. and Mohamed Ahmed, D., 1992. Biomasse et minéralomasse d'une plantation d'épicéa commun ( $P$ (ea abies Karst.) de forte production dans les Vosges (France). Ann Sci. For., 49: 651-668.

Soil Survey Staff, 1975. Soil Taxonomy. USDA Soil Conservation Service. US Government Printing Office, Washington $\mathrm{DC}, 754 \mathrm{pp}$.

Switzer, G.L. and Nelson, L.E., 1972. Nutrient accumulation and cycling in Loblolly Pine (Pinus laeda L.) plantation ecosystems: the first twenty years. Soil Sci. Soc Am. Proc., 36: 143-147.

Titus, J.S. and Kang, S.-M., 1980. Nitrogen metabolism, translocation and recycling in apple trees. Hortic. Rev, 6 : 204-246.

Tritton, L.M., Martin, C.W., Hornbeck, J.W. and Pierce, R.S., 1987. Biomass and nutrient removals from commercial thinning and whole-tree clearcutting of Central hardwoods. Environ. Manage., 11 (5): 659-666.

Turner, J., 1981. Nutrient cycling in an age sequence of western Washington Douglas-fir stands. Ann. Bot. 48: 159 169.

Turner, J. and Long, J.N., 1975. Accumulation of organic matter in a series of Douglas-fir stands. Can. J. For. Res., 5: $681-690$.

Van den Driessche, R., 1974. Predicting of mineral nutrient status of trees by foliar analysis. Bot. Rev., 40; 347-394.

Wells, C.G. and Jorgensen, J.R., 1979. Effect of intensive harvesting on mutrient supply and sustained productivity. 
In: Proc. of the Symposium Impact of Intensive Harvesting on Nutrient Cycling, State University of New York,
College of Environmental Science and Forestry, School of Forestry, Syracuse, NY, pp. 212-230. 